$\mathrm{DOI}$

УДК 57.043:636.034

ВЛИЯНИЕ ПРЕПАРАТА БИСОЛБИ НА БИОХИМИЧЕСКИЕ И ПРОДУКТИВНЫЕ ПОКАЗАТЕЛИ ТЕЛЯТ ГОЛШТИНО-ФРИЗСКОЙ ПОРОДЫ

\author{
Молянова Галина Васильевна, д-р биол. наук, проф. кафедры «Эпизоотология, патология и \\ фрармакология», ФГБОУ ВО Самарский ГАУ. \\ 446442, Самарская область, п.г.т. Усть-Кинельский, ул. Учебная, 2. \\ E-mail: Molyanova@yandex.ru \\ Ноготков Максим Павлович, аспирант кафедры «Эпизоотология, патология и фрармакология», \\ ФГБОУ ВО СамарскиЙ ГАУ. \\ 446442, Самарская область, п.г.т. Усть-Кинельский, ул. Учебная, 2. \\ E-mail: Molyanova@yandex.ru.
}

Ключевые слова: телята, добавка, Bacillus subtilis, Бисолби, показатель, биохимический, продуктивный.

Цель исследований - повышение среднесуточного прироста животных за счёт применения

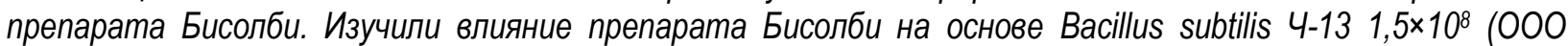
«Бисолби-Интер») на биохимические и продуктивные показатели телят. Научно-производственный опыт проводили на базе молочно-товарной феермы ГУП СО «Купинское» Самарской области на 30 телятах голштино-фризской породы. Биологическое действие препарата обусловлено адсорбционными свойствами, способностью усиливать активность ряда фрерментных систем и повышать кишечный и общий

иммунитет организма. Применение препарата повышает интенсивность анаболических процессов в организме животных: количество общего белка в сыворотке крови телят опытной группы

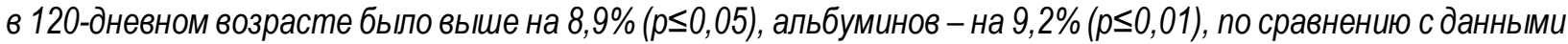
контрольных животных. Назначение Бисолби способствовало повышению интенсивности уелеводнолипидного обмена: количество холестерина было выше на 23\% ( $p \leq 0,01)$, содержание глюкозы на 0,4 ммоль/л $(p \leq 0,05)$ в крови 120-дневных телят опытной группы, по сравнению с данными контрольных животных. Установлено, что масса тела телят в контрольной группе в 100-дневном возрасте была $105,23 \pm 2,11$ ке, в опытной $-108,6 \pm 2,19$ ке, что на 3,37 ке выше. Среднесуточный прирост животных

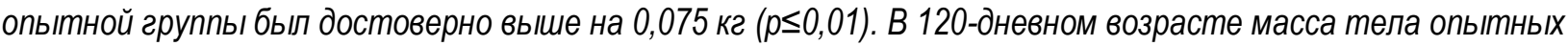

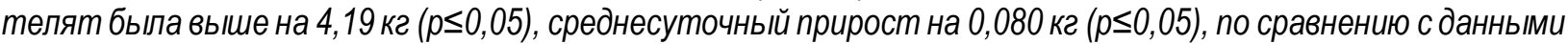
контрольных животных. Назначение 5-10 мл препарата Бисолби (ООО «Бисолби-Интер») телятам ежедневно в течение 2 месяцев обусловило получение условно дополнительной прибыли в 137 рублей от каждой головы.

\title{
THE EFFECT OF BISOLBI ON BIOCHEMICAL AND PRODUCTIVE PROCESSES OF THE HOLSTEIN-FRIESIAN CALVES
}

G. V. Molyanova, Doctor of Biological Sciences, Professor of the Department «Epizootiology, Pathology and Pharmacology», FSBEI HE Samara State Agrarian University.

446442, Samara region, settlement Ust-Kinelskiy, Uchebnaya street, 2.

E-mail: molyanova@yandex.ru

M. P. Nogotkov, Post-Graduate Student of the Department «Epizootiology, Pathology and Pharmacology», FSBEl HE Samara State Agrarian University.

446442, Samara region, settlement Ust-Kinelskiy, Uchebnaya street, 2.

E-mail: molyanova@yandex.ru

Keywords: calves, additive, Bacillus subtilis, Bisolbi, indicator, biochemical, productive.

The purpose of the research is increasing the average daily gain of animals due to the use of the Bisolbi drug. The effect of Bisolbi preparation based on Bacillus subtilis $\mathrm{H}-131.5 \times 10^{8}$ (LLC «Bisolbi-Inter») on the biochemical and productive life of calves was studied. The scientific and production experiment was carried out on the basis of a dairy farm of the State «Kupinskoe» Unitary Enterprise of the Samara region involving 30 Holstein-Friesian calves. The 
biological effect of the drug is provided due to its adsorption properties, the ability to enhance the activity of a number of enzyme systems and increase the digestive and systemic immunity of the body. The drug use increases the integration intensity of animals: the amount of total protein in the blood serum of calves of the experimental group at 120 days of age was higher by $8.9 \%$ ( $p<0.05)$, albumin - by $9.2 \%(p<0.01)$, compared with the animal data of controlled group. The Bisolbi indication contributed to an increase in the intensity of carbohydrate-lipoid metabolism: the cholesterol amount was higher by $23 \%(p<0.01)$, the glucose content - by $0.4 \mathrm{mmol} / \mathrm{l}(p<0.05)$ in the blood of 120 day old calves of the experimental group, compared with the data of controlled animals. It was found that the body weight of calves in the control group of 100 days age was $105.23 \pm 2.11 \mathrm{~kg}$, in the experimental group - $108.6 \pm 2.19 \mathrm{~kg}$, which is $3.37 \mathrm{~kg}$ higher. The average daily weight gain of animals in experimental group was significantly higher by $0.075 \mathrm{~kg}(\mathrm{p}<0.01)$. At 120 days of age, the body weight of the experimental calves was higher by $4.19 \mathrm{~kg}(\mathrm{p}<0.05)$, the average daily weight gain by $0.080 \mathrm{~kg}(\mathrm{p}<0.05)$, compared with the data of the controlled animals. The indication of Bisolbi 5-10 $\mathrm{ml}$ (LLC «Bisolbi-Inter») to calves daily for 2 months resulted in an additional profit constructively of 137 rubles from each head.

Выращивание молодняка - один из важных технологических процессов в животноводстве. Полноценное сбалансированное кормление телят дает возможность реализовывать заложенный в их породе генетический потенциал по получению высококачественной молочной или мясной продукции. Назначение пробиотиков в рационах молодняка сельскохозяйственных животных при интенсификации отрасли необходимо, так как оптимальное соотношение микрофлоры пищеварительного тракта легко нарушается при изменении типа питания, перегруппировке стада, высокой концентрации поголовья на единицу площади, лечении антибиотиками и сульфаниламидными препаратами. Учеными доказано, что применение минеральных адсорбентов, пробиотиков и других биологически активных веществ дополнительно к основному рациону приводит к улучшению обмена веществ организма сельскохозяйственных животных, повышению всасывания питательных веществ и уменьшению затраты кормов на единицу прироста живой массы $[1-2,5,10]$.

Бактерия Bacillus subtilis широко распространена в природе, часто встречается в пресной и морской воде, в ризосфрере, в почве, является ключевой грамположительной модельной бактерией для исследований в области физиологии и метаболизма. Благодаря своей высокоэффективной системе секреции белка и адаптируемому метаболизму микробные клетки Bacillus subtilis широко используются для производства рекомбинантных белков, особенно тех, которые связаны с производством химикатов, ферментов и антимикробных материалов для пищевой промышленности, сельского хозяйства и медицины.

По данным В. Е. Улитько и соавторов за период супоросности среднесуточный прирост у свиноматок, потреблявших биопрепарат 0,5\% Bisolbi, составил 404,1 г, что на 53,4 г (или 14,88\%) больше $(P<0,001)$, чем у контрольных животных. При дальнейшем увеличении до 1\% дозы Bisolbi в рационе свиноматок их среднесуточные приросты были на 97,65 г (или на 27,76\%) больше (P<0,001), чем у контрольных маток [7].

В ходе научного исследования Г. А. Ноздрин с коллегами доказали, что жидкие формы пробиотиков Ветом 2.26 (действующее начало - Bacillus subtilis штамм ВКПМ В-10641 и Bacillus amyloliquefaciens штамм ВКПМ В-10643 в количестве не менее $1 \times 10^{9}$ КОЕ/мл) и Ветом 4.24 (действующее начало - Bacillus amyloliquefaciens штамм ВКПМ В-10643 в количестве не менее $1 \times 10^{9} \mathrm{KOЕ/мл)} \mathrm{при} \mathrm{применении} \mathrm{новорожденным} \mathrm{телятам} \mathrm{обладают} \mathrm{выраженным}$ ростостимулирующим действием. Интенсивность роста подопытных телят находится в прямой зависимости от дозы препаратов. Самый высокий эфффект регистрировали в случае применения препаратов B дозе 1 мкл/кг массы, стимулирующий эффрект отмечали в течение 60 суток после прекращения применения препаратов [4].

B научных опытах J. Lu показал, что рекомбинантный B. subtilis значительно снижал вызванное алкоголем повышение индекса печени, содержание алкоголя в крови, активность аланинаминотрансфреразы, аспартатаминотрансферазы и щелочной фосффатазы в сыворотке крови мышей. Введение рекомбинантного B. subtilis ингибировало перекисное окисление липидов и окислительный стресс в печени лабораторных мышей, о чем свидетельствует значительное 
снижение уровня малонового диальдегида, индукция общей антиоксидантной способности и уровней глутатиона и супероксиддисмутазы [9].

В зависимости от биогеохимической специфичности территорий М. Н. Лежнина рекомендует применять свиньям безопасные, высокоэффективные биологически активные вещества нового поколения: Сувар, Полистим, Комбиолакс, воднит, шатрашанит.

Данные препараты способствуют проявлению организмом сельскохозяйственных животных стресс-резистентности и эврибионтности в различных агроэкологических условиях окружающей среды [3].

В ходе научной работы Н. М. Черноградская с коллегами выявили, что использование Сунтарского цеолита в опытных группах свиней позволило улучшить показатели роста и развития животных на 3,02 и 6,68\%, соответственно.

При этом по показателям среднесуточного прироста свиньи контрольной группы уступили опытным животным на 7,42 и 15,17\%. Установлена также разница в показателях морфологического состава откормочного молодняка свиней. Животные контрольной группы по количеству эритроцитов уступили опытным на 2,00 и 4,00\%; по количеству лейкоцитов контрольные животные уступили на 1,02 и $1,16 \%[8]$.

Использование современных отечественных биологически активных веществ, обеспечивающих улучшение физиологических и продуктивных показателей телят, является актуальной темой исследований.

Цель исследований - повышение среднесуточного прироста животных за счёт применения препарата Бисолби.

Задачи исследований - изучить влияние препарата Бисолби на гематологические и биохимические параметры крови телят голштино-фризской породы; 2) определить экономический эффект возможной прибыли от реализации мяса телят опытной группы.

Материал и методы исследований. Исследования проводились на базе кафедры «Эпизоотология, патология и фрармакология», в испытательной научно-исследовательской лаборатории факультета биотехнологии и ветеринарной медицины ФГБОУ ВО «Самарский государственный аграрный университет» и на молочно-товарной ферме ГУП СО «Купинское» Безенчукского района Самарской области.

Научно-производственный опыт провели на телятах 60-дневного возраста, подобранных по принципу аналогов с учетом породы, возраста, пола, массы тела, физиолого-клинического состояния и фризиологической зрелости. Животные контрольной группы получали основной рацион (ОР), сбалансированный по основным показателям питательности в соответствии с нормами РАСХН. Животные опытной группы - ОР с добавлением за 15-20 мин до кормления 5 мл раствора препарата Бисолби на основе Bacillus subtilis (60-90 дневным телятам) и 10 мл (91-120 дневным телятам) на голову 1 раз в сутки. Растворы телятам вводили через дренчер с соблюдением правил асептики и антисептики.

Бисолби - это биопрепарат, созданный ООО «Бисолби-Интер» (г. Санкт-Петербург). В состав входит Bacillus subtilis, штамм Ч-13, и метаболиты, полученные в процессе культивирования штамма в концентрации не менее 100 млн КОЕ/мл на наполнителе минерально-кремнеземистого порошка. Препарат имеет положительное экспертное заключение по токсиколого-гигиенической оценке штамма Bacillus subtilis Ч-13 от 30.03.2010 г. от научно-исследовательского центра токсикологии и гигиенической регламентации биопрепаратов.

Биологическое действие препарата обеспечивается его высокими адсорбционными свойствами и поверхностной активностью, что позволяет адсорбировать широкий спектр содержащихся в кормах микотоксинов, пестицидов, токсических металлов, радионуклидов и одновременно угнетать развитие патогенных и условно патогенных микроорганизмов, создавая благоприятные условия для развития в пищеварительном тракте лакто- и бифидобактерий, что в целом обеспечивает снижение токсической нагрузки на организм и одновременно усиливает активность ряда фрерментных систем организма животных [6].

В ходе научно-производственного опыта 15 телятам из каждой группы каждые десять дней проводили оценку физиолого-клинического статуса и роста тела. Забор крови для анализа 
осуществляли вакуумным способом из хвостовой вены до кормления в утренние часы с 60- и до 120-дневного возраста каждые 20 дней в течение научного эксперимента. Хозяйство благополучно по инфекционным заболеваниям крупного рогатого скота, вакцинация и дегельминтизация поголовья проводится согласно утвержденной схеме. Полученные в ходе эксперимента данные обработаны путём биометрии с вычислением общепринятых констант с помощью программы STADIA.

Результаты исследований. Зоогигиенические показатели в телятнике ГУП СО «Купинское» соответствуют стандартам содержания крупного рогатого скота. Микроклимат в помещении: температура воздуха в среднем $17,80 \pm 0,30{ }^{\circ} \mathrm{C}$; относительная влажность - $71,30 \pm 1,50 \%$;

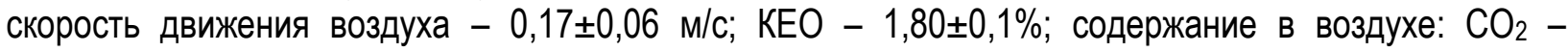
$0,16 \pm 0,04 \%$,

$\mathrm{NH}_{3}-9,00 \pm 0,20 \mathrm{Mr} / \mathrm{M}^{3}, \mathrm{H}_{2} \mathrm{~S}-2,40 \pm 0,20 \mathrm{Mr} / \mathrm{M}^{3}$.

Общие физиологические показатели: температура тела, частота пульса, дыхания у телят с 60- и до 120-дневного возраста изменялись равномерно и соответствовали календарному дню их развития. Температура тела животных находилась в пределах от $38,30 \pm 1,22$ до $38,79 \pm 1,170 \mathrm{C}$; частота пульса - от $103,49 \pm 1,31$ до $72,10 \pm 1,23$ ударов в минуту; частота дыхания - от $38,20 \pm 0,87$ до

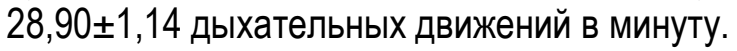

Влияние препарата Бисолби на основе Bacillus subtilis Ч-13 1,5×108 (000 «Бисолби-Интер») на гематологические и биохимические показатели крови телят голштино-фризской породы представлены в таблице 1.

Содержание эритроцитов и лейкоцитов в периферической крови животных опытной и контрольной групп в период применения препарата достоверно не различалось. Все изучаемые показатели находились в пределах физиологической нормы.

Основная функция гемоглобина - перенос кислорода к тканям. У телят, получавших дополнительно к основному рациону препарат Бисолби на основе Bacillus subtilis 4-13 1,5×108 (ООО «Бисолби-Интер»), наблюдалось достоверное повышение гемоглобина, по сравнению с контролем на $7,6 \%(p \leq 0,05)$, что указывает на более высокую интенсивность обменных процессов в организме телят.

Таблица 1

Гематологические и биохимические показатели крови телят

\begin{tabular}{|l|c|c|}
\hline \multirow{2}{*}{ Показатель, \% } & \multicolumn{2}{|c|}{ Группа } \\
\cline { 2 - 3 } & \multicolumn{2}{|c|}{ контрольная } \\
\hline \multicolumn{3}{|c|}{60 дней } \\
\hline Эритроциты, 1012/л & $6,09 \pm 0,28$ & $6,16 \pm 0,29$ \\
\hline Лейкоциты, 109/л & $7,11 \pm 0,32$ & $7,55 \pm 0,26$ \\
\hline Гемоглобин, \% & $119,20 \pm 1,32$ & $120,15 \pm 1,39$ \\
\hline Общий белок, г/л & $63,10 \pm 1,18$ & $63,30 \pm 1,26$ \\
\hline Альбумины, г/л & $21,72 \pm 0,46$ & $21,20 \pm 0,52$ \\
\hline Глобулины, г/л & $41,38 \pm 1,03$ & $42,1 \pm 1,15$ \\
\hline Глюкоза, ммоль/л & $2,5 \pm 0,07$ & $2,7 \pm 0,10$ \\
\hline Холестерин, ммоль/л & $2,72 \pm 0,08$ & $2,63 \pm 0,06$ \\
\hline Щелочная фосфатаза МЕ/л & $60,10 \pm 1,54$ & $59,50 \pm 1,78$ \\
\hline Общий кальций, ммоль/л & $2,01 \pm 0,04$ & $2,13 \pm 0,05$ \\
\hline Неорганический фосфор, ммоль/л & $1,66 \pm 0,06$ & $1,59 \pm 0,03$ \\
\hline \multicolumn{2}{|c|}{} & 120 дней \\
\hline Эритроциты, 1012/л & $6,00 \pm 0,44$ & $6,32 \pm 0,37$ \\
\hline Лейкоциты, 109/л & $6,68 \pm 0,29$ & $6,75 \pm 0,23$ \\
\hline Гемоглобин, \% & $119,20 \pm 1,95$ & $128,70 \pm 1,71^{*}$ \\
\hline Общий белок & $67,40 \pm 1,51$ & $73,40 \pm 1,24^{*}$ \\
\hline Альбумины & $22,90 \pm 0,37$ & $25,01 \pm 0,29^{*}$ \\
\hline Глобулины, г/л & $44,50 \pm 1,21$ & $48,39 \pm 1,15$ \\
\hline Глюкоза, ммоль/л & $3,3 \pm 0,09^{* *}$ \\
\hline Холестерин, ммоль/л & $2,9 \pm 0,11$ & $3,46 \pm 0,11^{* *}$ \\
\hline Щелочная фосффатаза МЕ/л & $2,81 \pm 0,09$ & $66,67 \pm 1,24$ \\
\hline Общий кальций, ммоль/л & $63,03 \pm 1,13$ & $2,36 \pm 0,05$ \\
\hline Неорганический фосфор, ммоль/л & $2,38 \pm 0,08$ & $1,94 \pm 0,07$ \\
\hline
\end{tabular}

Примечание (здесь и далее): * $-p \leq 0,05,{ }^{* *}-p \leq 0,01$ - относительно контрольных данных. 
Состояние белкового обмена определяется по содержанию общего белка. В организме белок выполняет следующие функции: участвует в свертывании крови, поддерживает постоянство рН крови, осуществляет транспортную функцию, участвует в иммунных реакциях и многие другие функции. Количество общего белка в сыворотке крови телят опытной группы в 120-дневном возрасте

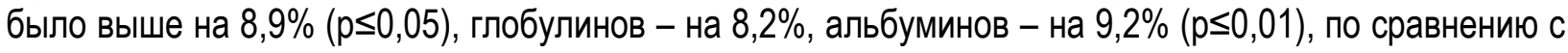
данными контрольных животных. Применение препарата Бисолби на основе Bacillus subtilis Ч-13 (ООО «Бисолби-Интер») повышает интенсивность анаболических процессов в организме животных, о чем свидетельствует более высокое содержание общего белка, конкретно его альбуминовой фракции.

Одним из показателей состояния углеводно-жирового обмена в организме животных является концентрация холестерина. На начало научного эксперимента содержание холестерина в крови телят обеих групп находилось в пределах фризиологической нормы и составляло 2,63-2,72 ммоль/л. Количество холестерина в сыворотке крови опытных телят в 120-дневном возрасте превышало показатели контрольных животных на 23\% $(p \leq 0,01)$. Глюкоза поддерживает нормальное функционирование индивидуальных клеток, органов и организма в целом. Содержание глюкозы в крови телят было в пределах физиологической нормы и находилось на уровне 2,5-3,3 ммоль/л. Результаты исследований показали, что содержание глюкозы в крови 120-дневных телят опытной группы было выше на 0,4 ммоль/л $(p \leq 0,05)$ и составляло 3,3 0,09 ммоль/л относительно данных животных контрольной группы. Применение препарата Бисолби телятам в течение 2 месяцев способствовало повышению интенсивности углеводно-липидного обмена.

Показателями состояния минерального обмена в организме являются общая концентрация кальция, неорганического фосфора и активность щелочной фоссфатазы в крови животных. В течение научного эксперимента все показатели находилась в пределах физиологической нормы,

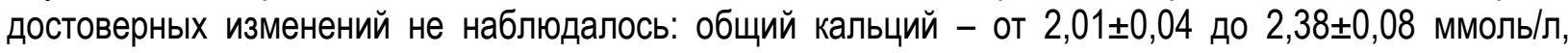

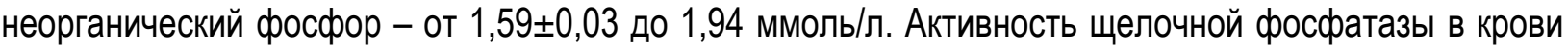
120-дневных телят, принимающих дополнительно к основному рациону препарат Бисолби на основе Bacillus subtilis Ч-13 (ООО «Бисолби-Интер»), превосходила показатель контрольных животных на 3,64 Ед/л (или на 5,46\%). Масса тела телят контрольной группы в 100-дневном возрасте была $105,23 \pm 2,11$ кг, в опытной $-108,6 \pm 2,19$ кг, что на 3,37 кг выше. Среднесуточный прирост телят опытной

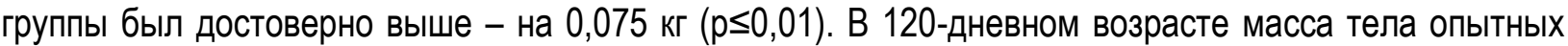

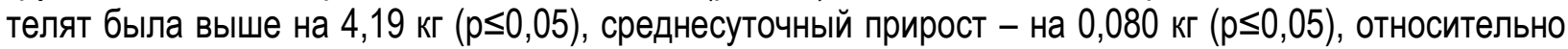
показателей контрольных животных. Применение препарата Бисолби на основе Bacillus subtilis Ч-13 (ООО «Бисолби-Интер») телятам в течение 2 месяцев способствовало увеличению среднесуточного прироста и интенсивности роста животных.

Экономические вычисления проводили с учетом затрат на производство мяса и полученной выручки от его реализации при цене 230 рублей за кг (по данным сайта «Самара - АРИС. АгроИнформ» от 15.12.2020 г. Режим доступа: http://www.agro-inform.ru/index.php/czenovoj-monitoring), а также договорной стоимости препарата Бисолби на основе Bacillus subtilis 350 рублей за 1 литр. На проведение профилактических мероприятий для одного животного за период научного эксперимента потратили 150 мл препарата, что соответствует сумме 52,5 рубля. Оплата труда ветеринарного фельдшера по спаиванию препарата теленку ежедневно за 2 месяца составила 712 рублей. На основании полученных данных рассчитали экономический эфффект от дополнительно полученной прибыли на момент окончания научно-производственного опыта. Применение препарата Бисолби способствовало повышению живой массы животного и возможному получению прибыли от реализации мяса телят опытной группы в 137 рублей от каждой головы.

Заключение. Параметры микроклимата в телятнике ГУП СО «Купинское» соответствовали зоогигиеническим нормам, установленным для данной возрастной группы животных. Назначение телятам голштино-фризской породы препарата Бисолби на основе Bacillus subtilis Ч-13 (ООО «Бисолби-Интер») в дозе 5-10 мл на голову дополнительно к основному рациону ежедневно в течение двух месяцев с 60-дневного возраста позволило повысить интенсивность роста животных. Можно рекомендовать препарат отечественного производства Бисолби в качестве биологически 
активной добавки для молодняка крупного рогатого скота с целью повышения среднесуточного прироста животных и получения условно дополнительной прибыли в 137 рублей от каждой головы.

\section{Библиографический список}

1. Баймишев, Х. Б. Инновационные технологии воспроизводства крупного рогатого скота в условиях интенсивной технологии производства молока / Х. Б. Баймишев, В. В. Альтергот, М. С. Сеитов // Известия Оренбургского ГАУ. - 2011. - № 32-1. - С. 110-113.

2. Дежаткина, С. В. Влияние цеолитовых добавок на показатели молочной продуктивности коров / С. В. Дежаткина, В. В. Ахметова // Ученые записки Казанской государственной академии ветеринарной медицины им. Н. Э. Баумана. - 2013. - Т. 214. - С. 148-154.

3. Лежнина, М. Н. Коррекция иммунофизиологического статуса боровков цеолитами разных месторождений в агропочвенных условиях юго-восточного региона Закамья / М. Н. Лежнина, Р. А. Шуканов, А. А. Шуканов // Наука и инновации - 2017 : материалы XII Международной научной школы. - Йошкар-Ола : Поволжский ГТУ, 2017. - C. 219-222.

4. Ноздрин, Г. А. Профилактическая и ростостимулирующая эфффективность жидких форм ветомов при применении их новорожденным телятам / Г. А. Ноздрин, А. Г. Ноздрин, А. Б. Иванова [и др.] // Достижения науки и техники АПК. - 2012. - № 10. - С. 60-62.

5. Равилов, А. 3. Влияние преминкора на клинические, гематологические и биохимические показатели крупного рогатого скота / А. З. Равилов, В. С. Угрюмова, А. П. Савельчев [и др.] // Ветеринария. - 2011. - №3. - C. 17-22.

6. Семёнова, Ю. В. Мясная продуктивность свиней при использовании в их рационе сорбирующей пробиотической добавки «Bisolbi» / Ю. В. Семёнова, Л. А. Пыхтина, А. В. Шуклина // Вестник Ульяновской государственной сельскохозяйственной академии. - 2017. - №4 (40). - С. 164-168.

7. Улитько, В. Е. Резервирование и использование питательных веществ свиноматками при обогащении их рационов пре-пробиотической добавкой Bisolbi / В. Е. Улитько, Л. А. Пыхтина, Ю. В. Семёнова [и др.] // Аграрная наука и образование на современном этапе развития: опыт, проблемы и пути их решения : материалы VIII Междунар. науч.-практ. конф. - Ульяновск, 2017. - С. 99-104.

8. Черноградская, Н. М. Рост и развитие, мясная продуктивность свиней при использовании в их рационах нетрадиционных кормовых добавок в Якутии / Н. М. Черноградская, Р. Л. Шарвадзе, М. Ф. Григорьев, А. И. Григорьева // Аграрная наука. - 2020. - №5. - С.40-44.

9. Молянова, Г. В. Воздействие препарата на основе Bacillus subtilus на росто-весовые параметры телят голштино-фризской породы / Г. В. Молянова, М. П. Ноготков // Известия Самарской ГСХА. - 2021. - №1. C. 46-51.

10. Lu, J. Alleviating acute alcoholic liver injury in mice with Bacillus subtilis co-expressing alcohol dehydrogenase and acetaldehyde dehydrogenase / J. Lu, Y. B. Lyu, M. T. Li [et al.] // Journal of functional food. - 2018. - Vol. 49. P. 342-350.

11. Zaitsev, V. V. Hemostasis and Rheological Blood Features Dynamics of Black-Many Coloured Lactating Cows at the Inclusion into their Ration of Antioxidant Lipisomal Preparation «Lipovitam-Beta» / V. V. Zaitsev, G. V. Molyanova, O. N. Makurina [et al.] // Biomedical and Pharmacology Journal. - 2017. - Vol.10, №10. - P. 759-766.

\section{References}

1. Baimishev, H. B., Altergot, V. V., \& Seitov, M. S. (2011). Innovacionnie tekhnologii vosproizvodstva krupnogo rogatogo skota v usloviiah intensivnoi tekhnologii proizvodstva moloka [Innovative technologies of cattle breeding in the conditions of intensive technology of milk production]. Izvestiia Orenburgskogo GAU - Izvestia Orenburg SAU, 321, 110-113 [in Russian].

2. Dezhatkina, S. V., \& Akhmetova, V. V. (2013). Vliianie ceolitovih dobavok na pokazateli molochnoi produktivnosti korov [Influence of zeolite additives on milk producing ability of cows]. Uchenie zapiski Kazanskoi gosudarstvennoi akademii veterinarnoi medicini imeni N. E. Baumana - Scientific notes of the Kazan State Academy of Veterinary Medicine named after N. E. Bauman, 214, 148-154 [in Russian].

3. Lezhnina, M. N., Shukanov, R. A., \& Shukanov, A. A. (2017). Korrekciia immunofiziologicheskogo statusa borovkov ceolitami raznih mestorozhdenii v agropochvennih usloviiah iugo-vostochnogo Zakamiia [Correction of the immunophysiological status of young gelded pig via use of zeolites of different deposits in the agropedological conditions of the Southeastern Zakamiye region]. Nauka i innovatsii - 2017 '17: mat. XII Mezhdunarodnoi nauchnoi shkoli - mat. XII International Scientific School. (pp. 219-222).Yoshkar-Ola: Povolzhsky STU [in Russian].

4. Nozdrin, G. A., Nozdrin A. G., \& Ivanova A. B. et al. (2012). Profilakticheskaia i rostostimuliruiushchaia effektivnost zhidkih form vetomov pri primenenii in novorozhdennim teliatam [Esophylactic and growth efficiency of vectomov liquid 
forms when feeding newborn calves]. Dostizheniia nauki i tekhniki APK - Achievements of Science and Technology of AlCis, 10, 60-62 [in Russian].

5. Ravilov, A. Z., Ugryumova, V. S., Savelchev, A. P., \& Savinkov, A. V. et al. (2011). Vliyanie preminkora na klinicheskie, gematologicheskie i biohimicheskie pokazateli krupnogo rogatogo skota [The influence of premincor on clinical, hematological and biochemical parameters of cattle]. Veterinariya - Veterinariya, 3, 17-22 [in Russian].

6. Semenova, Yu. V., Pykhtina, L. A., \&Shuklina, A. V. (2017). Myasnaia produktivnost svinei pri ispolizovanii v ih racione sorbiruiushchei probioticheskoi dobavki «Bisolbi» [Meat productivity of pigs when using the sorbing probiotic additive «Bisolbi» in their diet]. Vestnik Uliianovskoi gosudarstvennoi seliskokhoziaistvennoi akademii - Vestnik of Ulyanovsk state agricultural academy, 4 (40), 164-168 [in Russian].

7. Ulitko, V. E., Pykhtina, L. A., \&Semyonova, Yu. V. et al. (2017). Rezervirovanie i ispolizovanie pitatelinih veshchestv svinomatkami pri obogashchenii in racionov preprobioticheskoi dobavkoi Bisolbi [Reservation and use of nutrients by sows when enriching their diets with the pre-probiotic supplement Bisolbi]. Agrarian science and education at the present stage of development: experience, problems and ways to solving '17: materiali VIII Mezhdunarodnoi nauchno-prakticheskoi konferencii - proceedings of the VIII International Scientific and Practical Conference. (pp. 99-104).Ulyanovsk [in Russian].

8. Chernogradskaya, N. M. Sharvadze, R. L., Grigoriev, M. F., \& Grigoriev, A. I. (2020). Rost i razvitie, miasnaia produktivnost svinei pri ispolizovanii $v$ ih racionah netradicionnih kormovih dobavok $v$ Yakutii [Growth and gain of meat type pigs due to the use in their diets nontraditional additives of feed in Yakutiya]. Agrarnaya nauka - Agrarian science, 5, 40-44 [in Russian].

9. Molyanova, G. V., \& Nogotkov, M. P. (2021). Vozdeistvie preparata na osnove Bacillus subtilus na rostovesovie parametri teliat golshtino-frizskoi porodi [The effect of a preparation based on Bacillus subtilus on the height and weight parameters of calves of the Holstein-Friesian breed]. Izvestiia Samarskoi gosudarstvennoi selskokhoziaistvennoi akademii - Bulletin Samara state agricultural academy 1, 46-51 [in Russian].

10. Lu, J., Lyu, Y. B., \& Li, M. T. et al. (2018). Alleviating acute alcoholic liver injury in mice with Bacillus subtilis coexpressing alcohol dehydrogenase and acetaldehyde dehydrogenase. Journal of functional food, 49, 342-350.

11. Zaitsev, V. V.,Molyanova, G. V., Makurina, O. N., Savinkov, A. V., \& Uhtverov, A. M. et al. (2017). Hemostasis and Rheological Blood Features Dynamics of Black-Many Coloured Lactating Cows at the Inclusion into their Ration of Antioxidant Lipisomal Preparation Lipovitam-Beta. Biomedical and Pharmacology Journal, 10, 10, 759-766. 